\title{
The Italian Leadership on Inclusive Education: Myth or Reality?
}

\author{
Francesco Marsili, Annalisa Morganti, Alessia Signorelli \\ University of Perugia, 06123 Perugia PG, Italy
}

\begin{abstract}
Background: Italy is internationally known as a Country with a longstanding "tradition" of inclusive education.

Objective: Aim of the paper is to provide a frame on the educational policies that, since 1970s, have steered the school system according to a "fully inclusive" model, highlighting the instruments of teaching - learning and evaluation tools for assessing the quality of the inclusive processes.

Methodology: Starting from primary and secondary legislative sources, the paper identifies three main focus points: the passage from the inclusive "principle" to the teaching - learning practices; the tools for answering special educational needs; the tools for assessing the quality of inclusive processes.

Discussion: Even though there are many efforts to align to international legislative regulations and to modernize the concept of inclusive education, Italian reality seems to be ossified in self-referential attitudes, beliefs and practices that saturate the school system. The paper outlines the need for defining new systemic research approaches that can validate this long educational tradition.
\end{abstract}

Science Insights Education Frontiers 2021; 9(2):1241-1263.

Doi: 10.15354/sief.21.or048

How to Cite: Marsili, F., Morganti, A., \& Signorelli, A. (2021). The Italian leadership on inclusive education: Myth or reality? Science Insights Education Frontiers, 9(1):1241-1263.

Keywords: Inclusive Education, Italian Educational System, ICF, Individualized Educational Plan, Personalized Instruction Plan 
Marsili et al., The Italian Leadership on Inclusive Education.

About the Authors: Annalisa Morganti, Associate professor in Special Education at University of Perugia, 06123 Perugia PG, Italy.E-mail: annalisa.morganti@unipg.it

Alessia Signorelli, Research Fellow in Special Education at University of Perugia, 06123 Perugia PG, Italy. Email:alessia.signorelli@gmail.com

Correspondence to: Francesco Marsili, Ph.D. student, Human Sciences, University of Perugia, 06123 Perugia PG, Italy. E-mail: francesco marsili@hotmail.it

Conflict of Interests: None.

(C) 2021 Insights Publisher. All rights reserved.

(c) (i) (8) Creative Commons Non Commercial CC BY-NC: This article is distributed under the terms of the Creative Commons Attribution-NonCommercial 4.0 License (http://www.creativecommons.org/licenses/by$\mathrm{nc} / 4.0 /$ ) which permits non-commercial use, reproduction and distribution of the work without further permission provided the original work is attributed by the Insights Publisher. 


\section{Introduction}

T $\mathrm{N}$ the international horizon, Italy is considered a leading Country in the field of inclusive education (Begeny \& Martens, 2007). Starting from the 1970s, thus gaining half a century of experience and expertise, Italy contributed meaningfully to the development and renewal of inclusive school policies.

Aim of this paper is to provide a general frame on three main features of Italian school system concerning inclusion: educational policies, instructional tools and practices and, finally, evaluation and assessment of the whole system from an inclusive perspective.

After a first and delimited historical time period characterized by segregation and exclusion of students with disability from the main school system, Italy progressively proceeded in dismantling a "special" school approach through specific laws, opening the path to educational assimilation first and integration then of these students for the period covering mandatory inclusion. It was not until the 1980s that the right to education was extended to all students with disability also for the period of secondary school and only in 1990s such right was extended to kindergarten/early childhood education and care and University.

From age 0 to age 20 and beyond, still today, all students with every kind of disability, even the most severe, have access to mandatory and optional education, benefiting from a specific legislation regulating this path, recurring to paths and tools specifically defined that allow for personalizing and individualizing the teaching - learning processes.

The paper, through an historical - legislative excursus highlighting also the main theoretical models that evolved in the course of the time, addresses the current situation of the Italian school system from an inclusive perspective. This is done via the description of the most recent innovations in the educational laws area. Some critical issue highlighting an often-pronounced asynchrony between intention and implementation, between legislative evolution and educational research are also tackled.

National laws have brought to educational reflection and research's attention the methodological and instructional aspects usually solidly connected to the principle of school inclusion. In detail, the paper analyzes two instruments that in the daily teaching - learning allow for each teacher to make this very principle evident: the Individualized Educational Plan and the Personalized Instructional Plan. The different denomination, the different student population addressed and, most of all, the different use of these instruments and the recent developments are specifically discussed.

In the face of such large and brave legislation, of the many processes and products that in the course of the years contributed to giving Italy an international leadership position in the field of school inclusion, it is crucial to highlight that the validation of the historical choices made, beside many lights have also some substantial grey zones.

In its final part, the paper addresses the theme of assessing and evaluating the inclusive school system, a pivotal point in the validation of this long historical tradition that had really contributed to modifying, improving, and innovating a whole system. 


\section{The Italian Way to Inclusive Education between Past and Future}

The European document Support for Children with Special Education Needs (European Commission, 2013) describes the differences between the school systems of the various Member States of the European Union. It outlines how, notwithstanding EU regulations, recommendations and reports (UNESCO, 1994; UN, 2016; Watkins, 2012) provide a clear direction for what concerns the measures to take from an inclusive perspective together with the possibility for students with Special Educational Needs (SEN) of attending mainstream schools, there are still in some Countries educational realities that show the persistence of special schools or classes.

Even though the legislation, organizational, theoretical and practice framework in each national context appears to be quite heterogeneous in relation to the topics of inclusive education, therefore jeopardizing both the comparison of the systems themselves and the assessment of the efficacy of the inclusive practices (Cottini \& Morganti, 2015), the term "inclusive education" seem to reflect a model that takes on a general, rather shared meaning according to which inclusion means essentially assimilating students with SEN in mainstream classes (Nepi, 2013).

Italy, a unique case of 50 years of expertise in the field of inclusive educational policies in OCSE Countries, contributed meaningfully to the improvement and the overcoming of this narrow, reductive theoretical vision, dealing with the "challenge" of inclusion, starting from the 1960s and playing the role of both avantgarde and turning point at international level (Begeny \& Martens, 2007). The Italian model, as a matter of fact, represents an example of national policy that ensures access to all children and youths to school, from kindergarten to university, whichever their condition, even with severe disabilities (Ianes \& Dell'Anna, 2020).

Together with the changes occurred in the psychiatric field, Italy dismantled the "special" school system, opening to school integration (law 118/1971; law 517/1977) following a document of the parliamentary committee presided over by MP Falcucci, in 1975, that had already observed that "The whole school structure, particularly compulsory education, can and must decisively contribute to the overcoming of every situation of human, cultural and social exclusion that has its roots in the failure of the development of potential of the individual" (Circolare Ministeriale, 1975).

In this historical phase the concept of "assimilation" first and "integration" later covered an important role both in the pedagogical debate and the scholastic realities, were the introduction of the support teacher in each class in which there was a student with a certified disability represented an innovation and an element for an epistemological and methodological - instructional reflection.

Within this complex educational and policy framework (it is important to remember that in Italy there weren't different political stances on inclusive policies, not for what concerns their promulgation nor their implementation), the historic route to- 
wards inclusion presented the educational community with a cultural more than implementational issue.

If the assimilation in "normal" classes concerned mainly children and youths with disability, integration broadened the horizon of diversity, intercepting the students' needs, whichever they were, through a rethinking of the paradigmatic structure of diversities, differences and their related models (Sannipoli, 2015).

This theoretical shift corresponded to the succession and integration of different models: the clinical model, which sees disability as a problem of the person caused directly by a pathological condition linked to neurobiological determinants, and foresees the intervention of specialists in this field; the social model (Oliver, 1990) which, referring to the current of the Disability Studies (Medeghini et al., 2013) that challenges the assumption that causally connects impairment with being disabled, strongly emphasizes the context as the main obstacle to the full development of the person with disability. Therefore, according to this vision, society must be rethought and redesigned to cater for the needs of people with disabilities. These two models are synthesized in the framework law n.104 of 1992. Such law was concerned, and still is to these days, with social instances while aiming at ensuring full rights to persons with disability during their lifetime and in every context, from the educational to the job world.

The Italian way to a fully inclusive school model brought advancement in many fields of education. Particularly, an important innovation of the school system has been partially fulfilled by the law on the school autonomy (Presidential Decree n. 275/99), that gave each Italian school an organizational and most of all curricular flexibility that would allow each institute to adjust itself to its varied socio-cultural context. In this sense, the education provided by each school must globally and systemically tend towards an adjustment, in order to answer to the needs of the students of that specific area, which is often characterized, in some places of the Italian territory, by socio economic disadvantage or linguistic poverty.

The model of integration defined by Mitchell (2014) as "locating learners with special educational needs part-time in regular classes" (pp.298), was to be overcome in Italy with the coming of the capability approach whose underlying philosophy is the idea of quality of life, of well-being theorized by Amartya Sen (1993). This quality does not depend much on the means that each individual has at their disposal, rather on the ability to turn them in concrete actions and achievements oriented towards the life goals each one wishes to pursue.

The accent is on the real possibility of choosing actions, goals, and life plans to set and achieve, and within this freedom lies the concept of social justice. Overcoming disability does not equal to adjusting to "normality", rather it means broadening the individual's possibility of choice. Another innovation is represented by the International Classification of Functioning, Disability and Health (OMS, 2001), which saw the realization of the global collective effort of 191 Countries in order to embed all the models previously described in the biopsychosocial paradigm. However, in this phase between the late 1990s and early 2001, this "Copernican revolution" did not hold a legislative 
pivotal place in Italy, rather it contributed steering the educational research which conceptualized a "special normality" (Ianes, 2006).

Disability had a central role in laws and educational instances. ICF gave the issue a strongly innovative layer, embedding disability in a much wider frame which, learning from the clinical, social and capability models, has built at educational and school level a bridge between special education and full inclusion (Ahrbeck \& Felder, 2020).

Through the ICF's biopsychosocial frame, many interpretations have been given to disability in Italy.

From an educational perspective, disability is understood as "[...] the consequence of the profound interaction between the health of an individual and its life contexts, between personal and environmental factors. Starting from the functioning of each subject, the tool (ICF) possesses a universal value as it is concerned not only with people with disability but with the whole humanity and at the same time it promotes a multidisciplinary reading which allows for dialogue and exchange between different fields: the health one, the social one, the educational one, the clinical one and the statistical one." (Sannipoli, 2015).

What looks to be increasingly predominant is the need for a broader concept of inclusion which focal research point lies in interdisciplinarity.

Inclusion is an evolving phenomenon, socially and historically, which is being shaped as an empowerment movement aiming to a greater autonomy of the individual who becomes increasingly capable of making decisions about their life (Oliver, 1990).

With the ratification of the ONU Convention on the Rights of Persons with Disabilities (2006) through law n.18 of March 3 2009, Italy continues to follow its route towards inclusion, adapting its own rules to international legislative frameworks such as UNESCO's Policy guidelines on inclusion in education (2009) which state that "Inclusive education is a process of strengthening the capacity of the education system to reach out to all learners [...] An "inclusive" education system can only be created if ordinary schools become more inclusive - in other words, if they become better at educating all children in their communities" (UNESCO, 2009).

In the face of such international policies, Italy has increasingly adopted more focused national policies aimed at ensuring everyone the right to accessible education (law 107, 2010; Ministerial Decree /D.M. December 27/2012).

In particular, the D.M. of December $27^{\text {th }} 2012$ provides a specific direction for what concerns special educational needs which include disability, specific developmental disorders, socio -economical, cultural and linguistic disadvantage, and more recently, gifted children (MIUR, 2019). Actually, we see the opening of a double channel of educational care which entails personalization (Piano didattico personalizzato-Personalized Instructional Plan ${ }^{\underline{\underline{I}}}$ ) as further instructional action which sides the by now consolidated practice of individualization (Piano educativo individualizzato-Individualized Educational Plan²).

The inclusive paradigm has increasingly pushed towards participation which surely entails making decisions as well. Such paradigm has become an essential theoret- 
ical and reference framework only with the most recent laws (Dlgs 66, 2017, Dlgs 96, 2019) that have integrated ICF theoretical and practical structure, therefore strengthening those changes that step by step, lead to a new inclusive model.

What previously was called integration, was linked to a state, a condition, today inclusion represents rather a process, a philosophy of acceptance, namely to provide students - whatever their abilities, gender, language, culture-with a frame where they can be equally appreciated, respected and given equal educational opportunities (Mitchell, 2017).

\section{From the Principle of Inclusion to Inclusive Educa- tional Actions and Practices}

The educational policies for inclusion surely brought an important and remarkable contribution to the Italian school system from many perspectives. In this sense, we must think about instructional planning and design, and the experimentation of new technics and strategies (such as co-teaching, open instruction, differentiation). In particular, the support teacher, a key figure for the whole class and not only for the student with disability, is and always will be the pivot of change and shift towards inclusion, so much to allow us thinking about a future where each class, regardless of the presence of students with disability, will have a support teacher.

From this future perspective, inclusion broadens and permeates every aspect of the educational system becoming its main feature. The way toward inclusion, furthermore, has seen important innovations in the school spaces, a renewing of the learning environment and a technologization of the organizational-instructional structure. Inclusion, therefore, has been the "sounding board" that brought a continuous improvement to the Italian school system on different planes and levels.

In the intertwining of legislation and educational instances outlined until now, we must take into account not only the achievements but also the grey areas that within such a complex and longstanding educational system can lead to further, new developments. An example for this is the access to secondary schools for students with disabilities. There is a lack in the reorganization of the secondary school system that still today endures the model proposed by 1923's Riforma Gentile. This model, even though outdated by the unification of the 3-year junior secondary school (law 1859, 1962), does not facilitate access to high school to students with disabilities who are often pushed towards professional schools. The selection is therefore implicit and unclear, and this goes against the inclusive attitude that should characterize every school, in so far as what the principles of personalization and individualization previously explained call for.

This need is made clear by the data collected by the Ministry of Education ${ }^{\underline{3}}$ for the school year 2017/2018 which show that only $23.8 \%$ of the overall population of students with disability attend high schools, while $27.3 \%$ attends polytechnic schools, and the majority, $48.9 \%$ is enrolled in professional institutes. 
We see, therefore, the persistent scarcity of empirical evidence that would give each institution the chance to analyze the issues of the system. As it will be described in the last chapter of this contribution, even though the way towards inclusion had a crucial impact at a systemic level, contributing also to cultural progress, the lack of an evaluation and assessment system for the quality of inclusive education is a gap that must be filled as soon as possible. Even though this is one of the main points in the Italian educational debate on inclusion (Ianes et al. 2020), there is still no change of pace in its actual implementation due the negative convergence of legislative, economic, cultural and practical difficulties which makes more arduous implement and verify the effectiveness of inclusive educational practices and school policies (Cottini \& Morganti, 2015). Assessing the quality of inclusion would allow school to steer their educational horizons and find a way to include each and every one.

From this perspective, a snapshot on the current situation of the Italian school system show, on many aspects, an asynchrony between intention and actual implementation, between legislative process and educational research. A reading of the Italian model for inclusion shows the multidimensional connotation of this phenomenon, which is made of a principles level, an empirical evidence level, an organizational level and a methodological-instructional level (Cottini, 2019).

In this first section of the paper, we touched generally all of these levels. It is therefore crucial to highlight how these elements, from this asynchronous perspective, seem to have different paces and rhythms event though pursuing the same goal. In this aspect, the principles level seems to pull and steer the others, uncovering their shortcomings and flaws. The quality of inclusion, as already hinted, has been (and still is) an open debate for quite some years, but the evidence level and the organizational (policy) level seems yet unable to provide prompt answers. Furthermore, the biopsychosocial paradigm, even though it provided the key for understanding disability in terms of functioning, and by reason of the definition of paradigm given by Khun as "Universally recognized scientific conquests which, for a certain time, provide a model of problems and solutions that are acceptable to those who work in a given field of research" (Khun , 2009), could be read as a starting point and not a final destination.

In light of the new approaches to inclusion which look at diversity through an ecological - systemic lens besides functioning, we can hope, while thinking about inclusion, for the paradigm shift that Borland (2005) recalled in the field of gifted education and that Bocci (2021) wished so this concept would not be reduced simply to an elegant yet empty formula.

The paradigm shift is an overcoming of simple definitions and redefinitions, of categorization, of educational sectarism to approach a vision of inclusion oriented towards an educational-instructional action that can answer the needs of all students at all levels, in any environment and stage of life.

The ecological - systemic model for inclusion (Mitchell, 2015; Anderson et al., 2014), in this sense, provides an innovative outlook, which sees in the relation and inter-connections between different systems the only way of realization, outlining how at assessment, instructional, organizational and territorial level it is necessary to train, in- 
volve and cooperate with all the players of the educational process: teachers, school heads, families, educators, collaborators, policy maker and specialist. The ecological model, therefore, is the horizon towards which Italy is heading for a broadening of borders of school inclusion that can encompass social inclusion as well.

\section{Methodological Approaches to Inclusive Education in Italy: The Individualized Education Plan and the Per- sonalized Instruction Plan}

In the previous chapter, we explored the development of inclusive education in the Italian school system, together with the different frameworks implemented in the course of more than 50 years, outlining the evolution of the Italian inclusive approach to education.

The adoption of such different frameworks represents a number of pivotal shifts not only from a legislative standpoint, but it entails changes also in the more practical area of education, namely in the implementation of inclusive teaching - learning methodologies and strategies.

It is now clear that when we use the term inclusive education, we are referring, as Franceschini argues (2018) to a strongly participative approach to instruction which envisages the sharing of goals, objectives, and assessment methods; this stance is twofolded: on one side, there are ethical issues at stakes because it recognizes the importance of creating a democratic educational community and, on the other, we are faced with instructional issues, as when students are made aware of what is the school's educational plan and objectives, it is more likely for them to successfully reach their goals. This is where the concepts of individualization and personalization coming handy (Franceschini, 2018).

In the first chapter, we briefly touched two tools used by schools responding to these two ideas; the Individualized Educational Plan-IEP (in Italian: Piano Educative Individualization-PEI) and the Personalized Instructional Plan-PIP (Piano Didattico Personalization-PDP). Both are clear examples of how the Italian school system tried to establish a convergence between the legislative and the educational horizon, signifying the efforts put in the pursuit of a quality inclusive education.

However, there are differences in both documents, and differences with regards to the school population they are aimed at.

As a first step, it is important to operate a crucial distinction: the IEP is aimed at students with certified disabilities, while the PIP addresses the educational needs of students with learning disorders such as dyslexia, dyscalculia, and dysgraphia.

Another interesting fact is that while the IEP has been a stable instrument in the Italian schools for almost thirty years, the PIP is relatively younger, having been introduced in the educational system only ten years ago, with the law 170/2010 (later integrated with other memorandums and decrees) which was the first law ever to shed a 
light on the educational needs of those students with learning disorders attending Italian schools (Cottini, 2019; Magni, 2015).

\section{The Individualized Educational Plan}

The IEP is the document through which the educational and instructional goals for the student with certified disability are identified; even though it is a yearly document - that means it is necessary to revise and review it at the beginning of each new school year to assess its efficacy - the IEP is by no means a "fixed" tool as it is possible - and in some ways desirable - to carry out these actions during the school year as well to allow adjustments and modifications that would properly suit the student's progress, needs or achievement that could emerge in the course of school months.

The IEP is a thorough document which collects a series of crucial information useful for ensuring the educational and social wellbeing of the student; therefore, together with the detailed description of the educational and instructional interventions planned, the goals for the student and the criteria for evaluation and assessment, we also find sections dedicated to the organization of the school hours, a list of activities and the relative methodologies and resources to carry them out, the relationship between the school and the student's extra - school contexts, and the involvement of the families/caregivers. This plurality of circumstances is reflected by the fact that the IEP is drafted not only by the teaching staff, but it entails the participation of families and of all the public health professionals that attend to the student during therapy or rehabilitation activities outside the school. The engagement of these players in drafting the IEP contributes to the integration of additional, helpful information in order to create a more in-depth knowledge of the student which extends to their whole life inside and outside school (Ianes et al., 2010; Ianes \& Dell'Anna, 2020; Ianes \& Demo, 2017).

Therefore, the document on one hand aims at providing the school teaching staff (and not only the support teacher) with a holistic knowledge of the students both in terms of their functioning and aims of development, and on the other to draft a detailed plan for what concerns the student's goal and the routes to take to achieve them. In particular, special attention is given to the strengths of the students which constitute the foundations on which planning all the activities.

The IEP is part of the Educational and Instructional Syllabus of the School (in Italian Piano dell' Offerta Formativa - POF) which is drafted by every school in Italy to introduce and describe the educational and instructional choices and actions carried out by the institution. In the Syllabus are described also all the actions that the school intends to implement in order to adequately answer to the needs of students with disabilities, therefore acting as a "school plan for inclusion".

In recent years, the IEP has been subjected to significative changes and improvements, the most recent one represented by the intermenstrual decree n. 182 of December $29^{\text {th }}, 2020$, which defines new ways of allocating the support resources envisaged by the D.L 66/2017 and the new models for the IEP to be adopted by schools. 
The changes introduced by the decree provide an interesting landscape which, in turn, paves the way to further reflections about what in the first chapter have been defined as the difficulties of intersection between the laws and the reality of schools' daily life.

The most important of these innovations is, doubtlessly, the fact that in order to fill the new IEP document, the figures involved must now refer to ICF's biopsychosocial approach. If, before, the ICF framework had received wide consensus among the educational community but somewhat remained in the background, now it has gained the forefront, becoming the underlying set of principles guiding the methodological approach to inclusion-especially for what concerns the identification of facilitators or barriers to learning.

The adoption of the ICF framework represents a crucial change not only from a philosophical perspective but also from a practical standpoint; in fact, until now, the drafting of the IEP was made of two preliminary moments exemplified by two preparatory documents: the first one was the Functional Diagnosis (Diagnosi Funzionale)

Ianes et al., (2010) highlighted how its main goal was to get the more in-depth knowledge of the student and its functioning, therefore noting down strengths and weaknesses. However, the authors also stated that this knowledge should have been "educational - functional", namely useful to the daily and actual realization of appropriate, meaningful and effective instructional and educational activities. Further, the Functional Diagnosis was supposed to be seen as an interdisciplinary work; however, the responsibility for its drafting was of the specialist $\mathrm{MD}$, the pediatric neuropsychiatrists and the health professionals- this, according to Ianes et al. (2010) represented a mainly clinical - medical approach that went against the principles of shared tasks and transparency advocated at the beginning of this chapter - besides being a document that would provide little help to teachers for the planning of the individualized instruction thus becoming very little "functional" (Ianes et al., 2010). The second step was the Dynamic Functional Profile (Profilo Dinamico Funzionale) which was produced by the joint work of parents, curricular and support teaches together with health professionals. In the Dynamic Functional Profile were listed the student's strengths and weaknesses cognitive, communication, social, personal and learning areas (Cottini, 2019).

With the introduction of the ICF framework, these two documents become a thing of the past, at least in their formulation, and are replaced by the ICF Based Functioning Profile (Profilo di Funzionamento su Base ICF). Furthermore, the axes over which the strengths of the student are measured and that function as bases for planning the educational activities are divided in four dimensions: sociability and interaction; language and communication; autonomy and orientation; cognition, neuropsychology and learning. These four dimensions synthesize the previous parameters used in drafting the IEP up until last year.

With such a momentous changing, the Italian Ministry of Education has launched a specific section within its institutional website containing all the information - both legislative and practical - to be perused by all the players involved ${ }^{4}$ and where is 
possible to find information and training materials as the new IEP is still in its more testing phase.

Summing up, in the words of Pasqualotto \& Lascioli (2020), "The innovation introduced by the legislation is far-reaching, not only for the impact it has on the organization of the Services and on the procedures relating to school support and accompaniment towards the Life Project. Particularly relevant is the change of perspective brought by the adoption of the anthropological model of the International Classification of Functioning, Disability and Health (ICF). If, so far, the condition of disability has been assessed on the basis of clinical parameters, the Functioning Profile now requires a biopsychosocial assessment of the person which will consider not only deficits and impairments, as well as its effect on the development process of personal experiences (personal factors) and the setting of daily life (environmental factors). Indeed, this threefold focal lens is the only means to comprehend the overall condition of a person with disability - encompassing their needs and wishes - which is intertwined to the quality and the complexity of the social network to which they belong" (pp.43)

\section{The Personalized Instructional Plan}

While until now we focused our attention on the methodological approach to inclusive education for students with disability through the analysis of the Individualized Educational Plan, we can now explore another tool used by the Italian school system and especially aimed at students with learning disorders: the Personalized Instructional Plan PIP

The PIP has been introduced in Italy by the decree n.5669 of July $12^{\text {th }}, 2011$, containing the guidelines to the implementation of the framework Law 170 (Emili, 2020). The concept of PIP clearly calls to mind the need for a conscious, shared planning of the strategies, actions and instructional tools able to remove the barriers to learning and foster the achievement of students with learning disorders, which are measured on the real needs of the student themselves (Emili, 2020).

The PIP proposes strategies for supporting the student with learning disorders without contemplating the intervention of a support teacher but through the use of compensatory tools and dispensatory devices (Emili, 2020; Della Volpe, 2016; Fogarolo \& Ambrosini, 2013). According to Law 170, is responsibility of the teaching staff to identify the best compensatory devices that can support student's learning; these devices are proposed and agreed with the family and the student if they are of age, in order to make them the center of their learning (Della Volpe, 2016).

It is important to clarify the terms; with compensatory devices, we mean all the tools of technological and instructional nature that can facilitate the student's performance and allow them to concentrate on the cognitive aspects of the task; while, with dispensatory devices we refer to all those instructional and educational actions and strategies that relieve the student with learning disorder with performing a task that would be particularly difficult for them and would add nothing from a learning point of view (Della Volpe, 2016; Mansueti \& Cardellini, 2018). 
Two are the main approaches suggested while working on the inclusion of students with learning disorders: the implementation of an individualized instruction to be carried out during the individual tasks in the class and the personalized intervention that must be measured against the individual differences, carried out through the implementation of different methodologies and strategies while always keeping in mind the general and specific aspects of learning and performance (Mansueti \& Cardellini, 2018).

Until this point, we have analyzed the PIP as a document aimed at students with learning disorders but, as Fogarolo and Ambrosini (2013) argue, the Italian legislation on the inclusion of students with SEN in 2012 and later decrees, extended the possibility of drafting a personalization document - still called PIP - for students with SEN as well.

The application of the PIP in the area of SEN is, though, quite different from its use with students with learning disorders from a legislative and educational perspective - however, it can help whenever the teaching staff may encounter a student with a not specified or certified learning disorder (Fogarolo \& Ambrosini, 2013). In this case, the teaching staff must motivate the choice that urged them to use a PIP on educational instructional basis.

Therefore, while it is mandatory to draft a PIP for students with diagnosed and/or certified learning disorders, this is not the case with students with SEN that do not have diagnoses nor certified learning disorders but may show similar difficulties.

\section{Does this Mean Inclusive Quality?}

In this chapter we have summarized briefly the two main methodological tools used in Italian schools for the educational inclusion of students with disabilities and learning disorders. However, there are still many issues to deal with. The first one, and the most obvious, in a sense, is the lack of research able to produce sound evidence on the real impact of such tools on the quality of inclusive education.

While there is no doubt about their absolute pivotal role in ensuring access to education to all students, it is important to analyze how their use can produce an improvement on the many educational and instructional processes happening daily in the school. This is linked not only with the way the documents are structured but also to teachers (both curricular and support) readiness in approaching the drafting of these tools with a shared, focused and strong set of inclusive values that should not be reduced to declaration of intents. In the past years, the studies on the IEP in particular have been mainly focused on how to create better models for drafting it (Luciano \& Angelo, 2020) or have been of a more qualitative leanings with teachers being interviewed on their actual knowledge of the ICF framework (Chiaro, 2013).

Ianes and Demo (2017) argued how IEP's potential was at risk of being jeopardized by the inefficacy and ineffectiveness of its realization due to the complete lack of well-defined minimum quality standards, while clearly stating that the sole presence of the IEP is not enough to guarantee the quality of the inclusive courses, paths and pro- 
cesses offered by the schools, as its sound implementation needs to be carried out standing on quality principles.

While Montanari (2019) highlights how Italian schools should start a route of deep innovation of their "traditional ways" and must therefore review the objectives, methodologies and tools for achieving inclusion (and the extremely recent renovation of the IEP could be one example), it is also clear that it is not possible to think about renovation without testing the system and its components in order to identify "what works and in what circumstances" (Slavin, 2008) for a quality inclusive education.

This, in turn, is heavily linked to the questions concerning how to assess the quality of inclusive education through an evidence - based lens and what is the state of the art of the Italian education system in this regard - a pivotal issue that will be explored in - depth in the next chapter.

\section{Evaluation and Assessment Systems for the Quality of School Inclusion}

The first part of the contribution described in detail the sound, historic Italian's "tradition" of a fully inclusive school system. In the face of a school legislation that supported and still strongly supports such model, which entails the presence of every special need, from the most complex and severe disability to different types of disadvantages, it is not possible to ignore some still existing criticalities around the validation of such approach. In fact, the evidence able to substantiate and validate it is very scarce. We can say, in short, that all the conditions and premises to make Italian schools inclusive have been created, but it is also important to evaluate and assess as well how much they really are for the end users and for the whole school community.

In previous works (Cottini \& Morganti, 2015; Cottini et al., 2016) we extensively described the limits that characterize the Italian evaluation and assessment systems for what concerns school inclusion; these are the same limits that international literature has much highlighted.

In that regard, Begeny and Martens (2007), argue how in United States many supporters of a fully inclusive educational system have identified Italy as an excellent example of the realization of such policy but, at the same time, they still highlight how scarce is the research in Italy about inclusive practices and their outcomes and results.

The World Report on Disability by World Health Organization, in its most recent update as well (WHO, 2011), does not even cite the Italian model of inclusive education.

The weak link is surely represented by the paucity of applied research carried out with methodologies that can be brought back to Evidence-based Education applied to special education (Cottini \& Morganti, 2015; Dell'Anna \& Pellegrini, 2019). This limit, in addition to making problematic the validation of the organizational and didactical route of Italian school, does not provide teachers with sound methodological references in order for them to steer their daily work. 
Beginning in the Nineties, Italian schools started to pay attention to the evaluation and self-evaluation processes of the whole system, with the aim of a better distribution of resources and collection of the learning results of all students (Fiore \& Pedrizzi, 2016). Even though no real, systemic model had been defined, the recent national legislation about the educational inclusion of students with disabilities (DL 96, August $7^{\text {th }}$ 2019) needs to be credited for dedicating special attention to the "Evaluation and assessment of the quality of school inclusion" (art.4) as integral part of the assessment procedures of educational institutions. Entrusted with this process is the National Institute for the evaluation of the educational, instruction and training system (Istituto nazionale per la valutazione del sistema educativo di istruzione e di formazione INVALSI) in agreement with the Permanent Monitoring Unit for School Inclusion (established at the Ministry of Education since 1999).

The indicators for the evaluation and assessment of the quality of school inclusion specified by current legislation refer to criteria concerning: the implementation in schools of paths of personalization, individualization and differentiation for supporting students (Individualized Educational Plan and Personalized Instructional Plan); the level of involvement of the different players in the drafting of workplans for inclusion of selfevaluation kind (Plan for Inclusion); use of shared tools and criteria for assessing the learning outcomes of students and their social participation; the valorization of the professional competences of the school staff; accessibility and usability of school's resources, equipment, structures, materials and spaces.

Two are the main criticalities that must be currently highlighted; the first one is that this particular system of evaluation and assessment has yet to be achieved; the second has to do with the fact that such legislation is applied uniquely to students with a disability certification (Law 104/1992).

It is still unclear if this evaluation and assessment system, in its implementation phase, will concern somehow also students with other special educational needs. We should outline that Italian legislation specifically addressing students with disability does not make any reference to students with special educational needs even though, conversely, the laws regulating such needs embeds disability as well in their definition.

The 2012 document promulgated by the Ministry of Education called "Instruments for actions in support of students with special educational needs and territorial organization for school inclusion" (Strumenti d'intervento per alunni con bisogni educativi speciali e organizzazione territoriale per l'inclusione scolastica) makes it clear that in the definition of Special Educational Needs are included three main categories: disability, specific developmental disorders and socio-economic, linguistic and cultural disadvantages. As previously argued in the first chapter, since 2019, this concept has been extending to gifted students as well.

For what concerns the topic of assessing the quality of school inclusion Italy, therefore, must deal with a significative inclination toward new monitoring mechanisms which does not find a correspondence in the facts and actions carried out. Unfortunately, this stalemate perpetrates the lack of evidence on the efficacy of process and products 
that can guide and steer school policies towards change and continuous improvement, therefore impacting the decisional process and its implementation.

As recently outlined as well by Ianes and Dell'Anna (2020), the tendency in Italian empirical research, on the side of evaluation and monitoring of the inclusive school system, has been of mainly focusing on the structural and processual aspects, with a clear preponderance on descriptive studies that provide information on current or aptitudinal practices, leaving out important research aspects such as teachers, students and parent's point of view on disability and inclusion, the achievement of learning and social goals, the achievement of students with or without disability or other special educational needs, and on the efficacy of the practices and current intervention (Cottini \& Morganti, 2015)

We cannot ignore the real difficulties in obtaining empirical evidence supporting the process of inclusive education (Nepi, 2013) due to the variability of the conditions found within the same special educational needs, the different types of schooling taken into account, the methods, the tools used, the variables measured. These factors do not always allow for an objective and efficient generalization of the results, even beyond the geographical borders.

This leads to deem as determinant for obtaining the most complete and objective evaluation of the benefits produced by inclusion in common contexts in relation to inclusion in special contexts, not only the students' achievement in terms of grades and performance but, most of all, the different variables that from a methodological and organizational point of view contribute in identifying the complexity of the inclusive approach and the quality of inclusive instruction: the organization, the work methodology, teachers' willingness and training, the territorial alliances between the players involved, families' involvement, the quality of the interactions at all levels first of all social and cultural.

In terms of tools for assessing the construct of "inclusion", in relatively recent times, the Index for Inclusion: developing learning and participation in schools" (Booth \& Ainscow, 2002), translated in Italian as "Index per l'inclusione" (Booth \& Ainscow, 2011/2014), has become an important touchstone in the national context.

The Index, originating from United Kingdom and referring to a social model of disability and educational difficulties, explores the concepts of inclusion and exclusion through three main key dimensions: creating inclusive cultures, producing inclusive policies, developing inclusive practices.

Even if the definition of the indicators and the descriptors is clear, it is still a tool with an enough complex structure, made of about 150 items for each dimension. In the attempt of streamlining the Index's structure and make it more functional for the analysis of inclusion in an organizational model such as the Italian one, we worked on the creation and validation of a tool called "Inclusive Process Assessment Scale" ("Scala di Valutazione dei Processi Inclusivi") thanks to the project "Evidence Based Education: European Strategic Model for School Inclusion" funded by the ERASMUS+ Programme KA2 Strategic Partnership for School (EBE-EUSMOSI project Ref.no. 
2014-1-IT02-KA201-003578 - www.inclusive-education.net). This tool has been published in an open access journal in Italian language (Cottini et al., 2016).

In its final version, the scale, after quantitative and qualitative validation procedures, is made of two self-assessment sub-scales, each comprising of 20 items and one sub-scale with 15 indicators for an objective evaluation. Differently from the Index for Inclusion, the factor analysis carried out for the creation of the tool identified two factors that reflect on one hand the school's organization dimension and on the other the instructional practices.

The first dimension, called "inclusive organization", is assessed by the whole teaching staff of the school, including the school head.

Following, an example of item:

All teachers (curricular and support) are involved in the curriculum planning and evaluation in relation to every student (e.g. support activities are not planned, carried out and assessed only by the support teacher, etc.)

The second dimension is about "inclusive instruction" and is analyzed by the class' teachers.

Following, an example of item:

In support of those students that show different kinds of difficulties, are various forms of tutoring by more expert peers.

The scoring for each indicator of the two dimension is on a 4-level scale: 1 when the described circumstance never occurs or it occurs sporadically or it involves only one or very few people, highlighting a "very critical" situation; 2 when the described circumstance occurs rarely or involves only a few people, highlighting "some criticality"; 3 when the described circumstance happens quite frequently or involves the majority of the people, highlighting a "positive" situation; 4 when the described circumstance happens always or almost always or involves all the people, highlighting an "excellent" condition.

The Inclusive Process Assessment Scale, together with the self-assessment on the indicators of the two dimensions on inclusion, foresees the presence as well of questions which refer to objectively detectable parameters.

Following, an example:

How many training and discussion meetings have been organized during the school year on topics concerning inclusion which saw the participation of the school staff?

Options: None - From 1 to 2 - From 3 to 5 - More than 5

Please state the names of the meetings:

The use of the Inclusive Process Assessment Scale with vast samples of Italian schools (as well as Spanish and Croatian), thanks to its digital version, allowed both for the assessment of the efficacy of the schools (proved to be more or less inclusive) in terms of achieving the educational and instructional goals of the students, and for the impact of the programs of social emotional and prosocial education training programs on the quality of inclusive processes (Badia et al., 2020; Cottini 2019; Morganti, 2019; Morganti \& Roche 2017). The underlying intention is that this would become a tool 
used daily by teachers, able to facilitate the implementation of policies and practices steered towards the promotion of the quality of Italian schools from an inclusive standpoint.

The collected sound evidence plays a fundamental role in working towards the improvement of inclusion inside and outside school. The Scale also serves as an important aid in the process of self-assessment regarding one's own daily practices, particularly with reference to those concerning the didactic methodology used, and the structuring of learning time and space and/or teamwork between teachers. Data showed indeed a worrying situation, whose main critical issues are: a difficult external communication that, in turns, hinders the involvement of other players - both institutional and belonging to civil society-in school activities, curricula development and other activities aimed at inclusion, and in the matching of curricular and support activities in school.

EBE-EUSMOSI project results show that schools rarely promote debates with the community on the topic of inclusion and rarely organize refreshing training activities and courses concerning inclusive education in collaboration with professionals who take care for children with special educational needs. Initiatives involving families and aimed at making the inclusive dimension appreciated are rarely as well.

The results gained from previous research, together with a more recent literature review on the schoolwide approach to the assessment of inclusive education in Europe (Marsili et al., in press) clearly highlight the need for setting common assessment criteria and indicators for school inclusion, with the aim of building an efficient collaboration at all levels of the educational system (politics, leadership and end users). This is the goal of an innovative European research project called Algorithm for New Ecological Approaches to Inclusion (ECO-IN) ${ }^{\underline{5}}$. The project aims at investigating the right courses of action to improve the quality of school inclusion through a vision that is open to the territory, contemplating how the involvement of all the players and resources in the context where the school is located can be a determining factor. In other words, how to set a real policy of inclusion in Italy and Europe? For this end, we are developing an innovative, digitalized and multi-language system, based on a specific, reliable and valid algorithm-based scoring system for new ecological approaches on inclusion and for assessing and monitoring the processes of inclusive education carried out by the different target groups.

Recently, some assessment tools have been produced (Schurig et al., 2020) outlining the importance of the ecological and bio-ecological systems theories (Bronfenbrenner, 1976, Bronfenbrenner \& Morris, 2007) with the aim of helping understand the relationship between the factors and players that impact inclusive education.

Notwithstanding such encouraging signals, national and international studies about the responsibilities of the many players involved in inclusive education (teachers, school heads, collaborators, psychologists, policymakers, etc.) are still very limited. What is clearly lacking is a shared vision, with clear objectives to foster inclusion, that with engage all and that would allow, in addition, a continual exchange between social and educational inclusion. We hope for an increasing engagement of the different play- 
ers, especially at national level, in the monitoring, in the data collection, in the training processes and in the implementation of inclusive educational policies and practices.

\section{Conclusions}

Italian's school system has gone through many changes and shifts in pursuing of a fully inclusive system.

50 years of history in this sense - an educational - instructional as well as a legislative one - bear quite a testimony of this long journey.

However, for as many efforts have been made and still are, and inasmuch as these efforts show a willingness of improvement, there are gaps that should be filled.

One surely is the "double speed" of the legislative course and the actual school life and teachers' training, readiness and understanding of inclusion. While there are strives to align with the international legislative provisions to broadening and modernizing the concept of inclusive education, the educational reality seems to have come to a standstill, in what looks like a sclerotization of attitudes, beliefs and practices. This is what Ianes and Dell' Anna (2020) defined as the risks caused by a self-referential attitude that seems to saturate the Italian school system.

This criticality is not helped by the paucity of research and by various structural and organizational problems faced by schools both in their physical and philosophical environments.

In this paper we have provided a concise frame for what means to be inclusive in the Italian school system, putting together both the good practices and the shortcomings.

As all structures that have been standing and changing for such a long time, the Italian school system as well needs to be reviewed and revised in the light of global changes in terms of new approaches to teaching - learning strategies and methodologies and new ways of understanding what being "fully inclusive" means, educationally and socially - and let's not forget that education and society are closely intertwined in a feedback loop that informs and changes either in turns.

What surely emerged is the need for a new approach to research in order to gather data that would either support or push for the change of longstanding assumptions that may not be so scientifically sound - both from a practical - instructional and ethical perspective.

Inclusive education is both a process and a human stance; the Italian example, with its many lights as well as many shadows, can bring much to the international discourse. It just needs to find a new pacing that would keep up with the fast changes and innovations happening worldwide, welcoming them and merging them with what of good has to offer. 
Notes

1. The Personalized Instructional Plan - Piano Didattico Personalizzato (PDP) is a document drafted by the teaching staff (primary school) or by the class board (secondary school) for the organization of the dispensatory devices and the compensatory tools to allow students with SEN a fully inclusive education (D.M July $11^{\text {th }}$ 2011)

2. The Individualized Educational Plan-Piano Educativo Individualizzato (PEI) is an annual instructional and educational instrument, which refers to the educational and instructional goal, the tools and strategies to implement for achieving a learning environment able to promote the development of the capacities of students with disabilities and the fulfilling of the identified educational needs (D.M 182, 2020)

3. https://www.miur.gov.it/web/guest/-/scuola-on-line-i-dati-sugli-studenti-con-disabilita-riferitiall-anno-2017-20-1

4. https://www.istruzione.it/inclusione-e-nuovo-pei/

5. “Algorithm for new Ecological approaches to Inclusion" (ECO-IN) (Ref. 612163- EPP-1-20191-IT-EPPKA3-IPI-SOC-IN - EPPKA3) - Support for Policy Reform - Social inclusion in the fields of education and training. For further info please check: https:/leco-in.eu

\section{References}

Ahrbeck, B., \& Felder, M. (2020). Analysis of barriers to inclusive schools in Germany: Why special education is necessary and not evil. Education Science, 10(12):358. DOI: https://doi.org/10.3390/educsci10120358

Anderson, J., Boyle, C. \& Deppeler, J. (2014). The ecology of inclusive education. In: Zhang H., Chan P.W.K., \& Boyle C. (Eds), Equality in Education. Rotterdam: Sense Publishers https://doi.org/10.1007/978-946209-692-9_3

Ang, R.P., \& Huan, V.S. (2006). Relationship between academic stress and suicidal ideation: Testing for depression as a mediator using multiple regression. Child Psychiatry \& Human Development, 37(2):133-143. DOI: https://doi.org/10.1007/s10578-006-0023-8

Badia, M., Escotorín, P., Morganti, A., Roche, R. (2020). Educational intervention for an inclusive culture in primary school: The qualitative dimension of PRO-SEL programme. In J. Głodkowska (Ed.) Inclusive Education
- Unity in Diversity. Wydawnictwo

Akademii Pedagogiki Specjalnej. Warszawa. Polonia. pp.187-199. ISBN 978-83-978-8366010-74-1. [Italian]

Begeny, J.C., \& Martens, B.K. (2007). Inclusionary education in Italy: A little literature review and call for more empirical research. Remedial and Special Education, 28(2):8094.

https://doi.org/10.1177/07419325070280020 701

Bocci, F. (2021). Laura Conti, una pioniera della visione inclusiva della società. [Laura Conti, a pioneer of the inclusive vision of society] L'integrazione scolastica e sociale, 20(1):157-168. [Italian] DOI: https://doi.org/10.14605/ISS2012107

Booth, T., \& Ainscow, M. (2002). Index for Inclusion: Developing learning and participation in schools (revised edition 2011). CSIE, New Redland Building, Coldharbour Lane, Frenchay, Bristol BS16 1QU, UK. 
Trad. It. Nuovo Index per l'inclusione. Percorsi di apprendimento e partecipazione a scuola. Roma: Carocci. [Italian]

Borland, J.H. (2005). Gifted education without gifted children: The case of no conception of giftedness. In R. J. Sternberg \& J. E. Davidson (Eds.), Conceptions of giftedness (pp. 1-19). Cambridge University Press. DOI: https://doi.org/10.1017/CBO9780511610455 .002

Bronfenbrenner, U. (1976). The Experimental Ecology of Education. Educational Researcher, 5(9):5-15. DOI: https://doi.org/10.3102/0013189X00500900 $\underline{5}$

Bronfenbrenner, U., \& Morris. P. (2007). The Bioecological Model of Human Development. In W. Damon, \& R.M. Lerner (Eds.), Handbook of Child Psychology (pp.793828). New York: Wiley. DOI: https://doi.org/10.1002/9780470147658.chps $\mathrm{y} 0114$

Chiaro, M. (2013). L'ICF-CY per la progettazione inclusiva per gli alunni con DSA, Form@ re Open Journal per la formazione in rete, 13(3):80-89. [Italian] DOI: https://doi.org/10.13128/formare$\underline{13627}$

Circolare Ministeriale del 8 agosto 1975, n. 227. "Interventi a favore degli alunni handicappati”.

Cottini L., \& Morganti A. (2016). Does the school inclusion really work? Education Sciences \& Society, 7(1):13-32. DOI: http://dx.doi.org/10.3280/ess1-2016oa3240

Cottini L., Fedeli D., Morganti A., Pascoletti S., Signorelli, A., Zanon F. \& Zoletto D. (2016). Una scala per valutare l'inclusività delle scuole e delle classi italiane. Form@re. Open Journal per la formazione in rete, 16(2):65-87. [Italian] DOI: http://dx.doi.org/10.13128/formare-18512

Cottini, L. (2019). Didattica speciale e inclusione scolastica. Roma: Carocci.

Cottini, L., \& Morganti, A. (2015). EvidenceBased Education e pedagogia speciale. Principi e modelli per l'inclusione. Roma: Carocci. [Italian]

Dell'Anna, S., \& Pellegrini, M. (2019). Condurre systematic review in ambito inclusivo. Uno strumento per

l'epistemologia e l'implementazione nel settore, In D. Ianes (a cura di), Didattica e inclusione scolastica. Milano: FrancoAngeli. pp.162-174. Retrieved March 04, 2021 from http://ojs.francoangeli.it/_omp/index.php/oa/ catalog/book/458 [Italian]

Della Volpe, V. (2016). Study of compensatory tools and dispensatory devices in Italian inclusive education. Journal of Research \& Method in Education, 6(5):7-13. DOI: https://doi.org/10.9790/7388-0605010713

Emili, E.A. (2020). Dislessia. Progettualità educative e risorse compensative. Bononia University Press: Bologna. [Italian]

European Commission. (2013). Support for Children with Special Education Needs. Retrieved March 06, 2021 from https://ec.europa.eu/social/BlobServlet?docI $\mathrm{d}=15993 \&$ langId $=\mathrm{en}$

Fiore, B., \& Pedrizzi, T. (eds.). (2016). Valutare per migliorare le scuole. Firenze: Mondadori Università. [Italian]

Fogarolo, F., \& Ambrosini, M. (2013). Costruire il Piano Didattico Personalizzato: Uno strumento per migliorare e semplificare la redazione del PDP per gli alunni con DSA. Difficoltà di Apprendimento e Didattica Inclusiva, 1(2):173-192. [Italian] https://www.istitutogritti.it/rolp/convegnoFo garolo/Fogarolo_DSAcostruire_il_PDP_soft ware.pdf

Franceschini, G. (2018). Didattica inclusiva: aspetti metodologici, epistemologici e percorsi di ricerca. Studi sulla Formazione, 21(2):201-216. [Italian] https://www.torrossa.com/en/catalog/previe $\mathrm{w} / 4461415$

Ianes, D. \& Dell'Anna, S. (2020). Valutare la qualità dell'inclusione scolastica. Un framework ecologico. L'integrazione scolastica e sociale, 19(1):109-128. [Italian] DOI: https://doi.org/10.14605/ISS1912011

Ianes, D. (2006). La Speciale normalità Strategie di integrazione e inclusione per le disabilità e i Bisogni Educativi Speciali. Trento: Erickson. [Italian]

Ianes, D., \& Demo, H. (2017). Il Piano Educativo Individualizzato: luci e ombre di quarant'anni di storia di uno strumento 
fondamentale dell'Integrazione Scolastica in italia. L'integrazione scolastica e sociale, 16(4):415-426. Available at:

https://bia.unibz.it/esploro/outputs/journalAr ticle/Il-Piano-Educativo-Individualizzatoluci-e-ombre-di-quarantanni-di-storia-diuno-strumento-fondamentaledellIntegrazione-Scolastica-initalia/991005772998701241

Ianes, D., Demo, H., \& Dell'Anna, S. (2020). Inclusive education in Italy: Historical steps, positive developments, and challenges. Prospects, 49(3):249-263. DOI: https://doi.org/10.1007/s11125-020-09509-7

Ianes, D., Demo, H., Cramerotti, S. (2010). Piano educativo individualizzato: Diagnosi funzionale, Profilo dinamico funzionale, attività e interventi. Retrieved March 04, 2021 from

http://www.mariomalizia.it/scarico_materiali /janes.pdf [Italian]

Khun, T. (2009). La struttura delle rivoluzioni scientifiche. (A., Carugo, Trans) Milano: Einaudi. (Original work published in 1962) [Italian]

Magni, F. (2015). L'integrazione scolastica delle persone con disabilità, disturbi specifici di apprendimento (DSA) e bisogni educativi speciali (BES). Framework normativo e giurisprudenziale aggiornato. Nuova Secondaria, 32(9):22-42. [Italian] http://www.snalsbrindisi.it/documenti/doc2/ Magni.pdf

Mansueti, E., \& Cardellini, L. (2018). Bisogni educativi speciali: il modello italiano nel contesto internazionale. Retrieved March 04, 2021 from https://www.indire.it/wpcontent/uploads/2018/01/bes-sintesi.pdf [Italian]

Marsili, F., Morganti, A., \& Sisti, F. (in press) L'approccio schoolwide alla valutazione dell'inclusione scolastica in Europa: una revisione della letteratura. Giornale Italiano dei disturbi del Neurosviluppo. [Italian]

Medeghini, R., D'alessio, S., Marra, A., Vadalà, G., \& Valtellina, E. (2013). Disability Studies. Emancipazione, inclusione scolastica e sociale, cittadinanza. Trento: Erickson.

Mitchell, D. (2014). What really works in special and inclusive education: Using evi- dence-based teaching strategies? London: Routledge.

Mitchell, D. (2015). Inclusive education is a multi-faceted concept. Center for Educational Policy Studies Journal, 5(1):9-30. https://ojs.cepsj.si/index.php/cepsj/article/vie W/151

Mitchell, D. (2017). Diversities in education: Effective ways to reach all learners. New York: Routledge.

MIUR, Ministero dell'Università e della Ricerca. (June 03, 2019). Scuola, on line i dati sugli studenti con disabilità riferiti all'anno 2017/2018. Retrieved March 08, 2021 from https://www.miur.gov.it/web/guest/-/scuolaon-line-i-dati-sugli-studenti-con-disabilitariferiti-all-anno-2017-20-1 [Italian]

Montanari, M. (2019). Un bilancio critico sull'inclusione degli alunni con "bisogni educativi speciali" in Italia. [The inclusion of "special educational needs" pupils. A critical assessment] Italian Journal of Special Education for Inclusion, 7(2):351-370. DOI: https://doi.org/10.7346/sipes-02-2019-26 [Italian]

Morganti A., \& Roche R. (2017). Prosocialità ed emozioni: un'alleanza per l'inclusione a scuola. Psicologia e Scuola, 50:30-37. [Italian]

Morganti, A. (2019). Un modello strategico europeo per l'inclusione a scuola. Evidenze che guidano e ispirano". L'Integrazione Scolastica e Sociale, 17(2):118-120. [Italian] https://rivistedigitali.erickson.it/integrazione -scolastica-sociale/it/visualizza/pdf/1734

Nepi, L.D. (2013). Includere fa la differenza? Il punto alla luce delle evidenze empiriche. Form@re Open Journal per la formazione in rete, 13(3):27-41. [Italian] DOI: https://doi.org/10.13128/formare-13625

Oliver, M. (1990). The politics of disablement. London: Macmillan Publishers Limited.

OMS. (2007). International Classification of Functioning, Disability and Health. Trento: Erickson.

Pasqualotto, L., Lascioli, A. (2020). Il profilo di funzionamento su base ICF: esiti di una sperimentazione. Journal of advanced health care. 2(1):43-48. Available at: 
https://jahc.eu/wp-

content/uploads/2020/04/JAHC2001-004.pdf

Sannipoli, M. (2015). Diversità e differenze nella prospettiva coevolutiva. Milano:

FrancoAngeli.

Schurig, M., Weiß, S., Kiel, E., Heimlich, U., \& Gebhardt, M. (2020). Assessment of the quality of inclusive schools A short form of the quality scale of inclusive school development (QU!S S) - reliability, factorial structure and measurement invariance. International Journal of Inclusive Education, 1-16. DOI:

https://doi.org/10.1080/13603116.2020.1862 $\underline{405}$

Sen, A. (1993). Capability and Well-Being. In M., Nussbaum, \& A., Sen, The Quality of Life. Oxford: Clarendon Press.

Slavin, R. E. (2008). What Works? Issues in Synthesizing Educational Program Evaluations. Educational Researcher. 37(1):5-14. https://www.jstor.org/stable/30133882

UN. (2016). Convention on the Rights of Persons with Disabilities (CRPD). Retrieved March 06, 2021, from

https://www.un.org/development/desa/disabi lities/convention-on-the-rights-of-personswith-disabilities.html

UNESCO. (2009). Policy guidelines on inclusion in education. United Nations Educa-
tional,Scientifi c and Cultural Organization. Retrieved March 08, 2021 from https://unesdoc.unesco.org/ark:/48223/pf000 0177849

UNESCO. (June 7-10, 1994). The Salamanca statement on principles, policy and practice in special needs education and framework for action on special needs education. United Nations Educational, Scientific and Cultural Organization Ministry of Education and Science Spain. Retrieved March 06, from https://unesdoc.unesco.org/ark:/48223/pf000 $\underline{0098427}$

Watkins, A. (2012). Teacher education for inclusion: Profile of inclusive teachers. European Agency for Development in Special Needs Education. Retrieved March 06, 2021 from https://www.european-

agen-

cy.org/sites/default/files/profile_of_inclusive _teachers_en.pdf

WHO. (January 01, 2011). World report on disability 2011. Geneva, Switzerland: World Health Organization. Retrieved March 08, 2021 from

https://www.who.int/teams/noncommunicabl e-diseases/sensory-functions-disability-andrehabilitation/world-report-on-disability 